\title{
Hacia la fibra de carbono en la construcción
}

\section{Towards the carbon fibers in the building industry}

\author{
A. MIRAVETE \\ Universidad deZaragoza
}

Fecha de recepción: 26-VI-2001

ESPAÑA

\section{RESUMEN}

En el área de fibra de carbono en la construcción hay actualmente dos líneas de trabajo: reparaciones $e$ implantación en obra: La implantación en la obra civil está avanzando más despacio que la utilización en reparaciones debido al bajo coste de los materiales tradicionales, a la limitación de procesos de fabricación de estructuras de materiales compuestos y al conservadurismo de las normativas de edificación y obra civil en todos los países industrializados. Sin embargo, los tres asuntos mencionados están siendo abordados con eficiencia, como se explicará más adelante.

En el presente artículo, se va a describir, el primer lugar, la fibra de carbono, sus tipos, procesos de fabricación y presentaciones industriales. En segundo lugar se tratarán las aplicaciones en la construcción, haciendo énfasis en las reparaciones y en la implantación en obra civil.

\author{
SUMMARY
}

There are two mainstreams in the building industry in the area of carbon fibers: rehabilitation and use as building material. The using of carbon fiber as a building material is taking place slower than as rehab system due to the very low cost of traditional building materials, the limitations of composite structure manufacturing processes and the conservative building regulations concerning materials in all the industrialized countries. However, these three issues are being solved in a very efficient way, as we will see along the coming paragraphs of this paper.

This paper is split in two parts, first the carbon fiber as a material system, its typologies, manufacturing processes and industrial presentations will be described. Second, rehab and building applications will be analyzed.

\section{INTRODUCCIÓN}

La producción de fibra de carbón a lo largo de la década de los noventa pasó de siete a veinte toneladas. Se espera que dentro de diez años supere las quinientas. $\mathrm{La}$ razón de este incremento radica en el coste, que ha bajado drásticamente en los últimos años pasando de $50-250$ euros $/ \mathrm{kg}$ hasta los 10 euros $/ \mathrm{kg}$ que tenemos actualmente. Esta reducción ha implicado que la fibra de carbono haya dejado de ser un material netamente aeronáutico como ocurría en las décadas de los setenta y los ochenta para pasar a ser un material multi-sector. A principios de la década de los noventa comenzaron a utilizarse en artículos de deporte: palos de golf, raquetas, etc. Hoy en día hay dos campos donde esta fibra está emergiendo con consumos potenciales muy elevados: la construcción y el automóvil.

En la construcción hay dos líneas de trabajo: reparaciones e implantación en obra. Edificios y sobretodo puentes en todo el mundo son reparados con fibra de carbono de forma muy eficiente frente a las técnicas tradicionales. Las láminas metálicas adheridas al hormigón mediante resina de epoxi se utilizan desde hace cuarenta años. Sin embargo, la lámina metálica presenta serios problemas como se indicará a lo largo del artículo.

La implantación en la obra civil esta avanzando más despacio que la utilización en reparaciones debido al bajo coste de los materiales tradicionales, a la

\section{INTRODUCTION}

The production of carbon fiber in the 90's increased from seven (1990) to twenty tons (1999). A production of 500 tons in expected in ten years time. The reason behind this high increase rate is based on the cost reduction from $50-250$ euros $/ \mathrm{kg}$ to 10 euros $/ \mathrm{kg}$, which is the current large tow carbon fiber cost. The carbon fiber, which was just an aerospace material in the 70's and the 80's, is now a multi sector material due to this cost reduction. At the early 90's, the carbon fiber were first used in sporting goods, such as golf shafts, tennis racquets, etc. Nowadays, carbon fiber consumption is expected to increase largely in two fields: building and automotive industries.

There are two mainstreams in the building industry: rehabilitation and use as building material. Buildings and above all bridges are being rehabilitated and repaired by means of carbon fiber systems in a very efficient way in comparison with the traditional technologies. The metallic sheets adhered to the concrete are used for the last forty years, however this material presents serious difficulties as will be reported along this paper.

The using of carbon fiber as a building material is taking place slower than as rehab system due to the very low cost of traditional building materials, the 
limitación de procesos de fabricación de estructuras de materiales compuestos y al conservadurismo de las normativas de edificación y obra civil en todos los países industrializados. Sin embargo, los tres asuntos mencionados están siendo abordados con eficiencia como se explicará más adelante.

Este artículo consta de dos partes, en primer lugar se va a describir la fibra de carbono, sus tipos, procesos de fabricación y presentaciones industriales. En segundo lugar se van a tratar las aplicaciones en la construcción, haciendo énfasis en las reparaciones y en la implantación en obra civil.

\section{LAS FIBRAS DE CARBONO}

Las fibras de carbono fueron utilizadas por Edison en el siglo XIX como filamentos para bombillas. La investigación que dio como resultado el uso de estas fibras en los materiales compuestos modernos, se atribuye a los trabajos de principios de los años sesenta de Shindo en Japón, Watt en Inglaterra y Bacon y Singer en los Estados Unidos. Aunque se ha investigado una gran cantidad de materiales como precursores de esta fibra, el poliacrilonotrilo (PAN), una mesofase del alquitrán ("pitch") y la celulosa (en orden decreciente de uso actual), son los tres precursores que actualmente se utilizan para su fabricación. Las fibras que están basadas en el PAN tienen diámetros que oscilan entre las 5 y $7 \mu \mathrm{m}$, y aquéllas cuyo precursor es el alquitrán están entre las 10 y $12 \mu \mathrm{m}$.

El poliacrilonitrilo es el precursor más común utilizado actualmente para obtener fibras de carbono, y generalmente no es PAN al $100 \%$. Normalmente, es un copolímero que contiene metil acrilato, metil metacrilato, vinil acetato, ácido itacónico, o cloruro de vinilo. El PAN (o su copolímero) es hilado utilizando la técnica de hilado húmedo (la técnica de hilado fundido se ha desarrollado también para el hilado del PAN).

En la Figura 1 se muestra un esquema de la conversión de la mesofase de alquitrán y la del PAN en fibra de carbono. La mesofase líquida cristalina de alquitrán se utiliza para obtener fibras de alto módulo. Petróleo, carbón mineral, y policloruro de vinilo son las fuentes comunes del alquitrán utilizado para obtener estas fibras.

La fibra de carbono es un material excepcional para aplicaciones de estructuras sometidas a cargas repetitivas o fatiga ya que es el único material conocido cuyas propiedades mecánicas apenas son sensibles a la aplicación de una carga cíclica. También en lo que se refiere a su comportamiento en limitations of composite structure manufacturing processes and the conservative building regulations concerning materials in all the industrialized countries. However, these three issues are being solved in a very efficient way, as we will see along the coming paragraphs of this paper.

This work is split in two parts, first the carbon fiber as a material system, its typologies, manufacturing processes and industrial presentations will be described. Second, rehab and building applications will be analyzed.

\section{CARBON FIBERS}

Carbon fibers are known since Thomas Edison developed the incandescent light in the Nineteenth century. However these fibers were not produced in large quantities until the late 60's based on works from Shindo (Japan), Watt (England) and Bacon and Singer (USA). Though a number of precursors have been studied, only the polyacrylonitrile (PAN), pitch based on petroleum asphalt, coal, tar and polyvinyl chloride - and rayon, which is derived from cellulosic materials are the three used most currently. The carbon fibers from $P A N$ present diameters ranging from 5 and $7 \mu \mathrm{m}$, and those from pith, between 10 and $12 \mu \mathrm{m}$.

The polyacrylonitrile is the most used precursor to produce carbon fibers and generally, is not PAN at $100 \%$, but a copolymer composed of methyl acrylate, methyl methacrylate, vinyl acetate, acid itaconic and polyvinyl chloride. The PAN (orits copolymer) is spooled by means of the technique of wet spooling (the technique of the cast spooling has also been developed for PAN fibers).

A scheme of the mesophase conversion of pitch and $P A N$ fibers is represented in Figure 1. The liquid crystalline mesophase of pitch is used to obtain high modulus carbon fibers. Petroleum asphalt, coal, tar and polyvinyl chloride are the usual sources to produce pitch fibers.

The carbon fiber is an exceptional material for structural applications with fatigue loadings since it is the only material known whose mechanical properties are barely affected by a cyclic load. In 


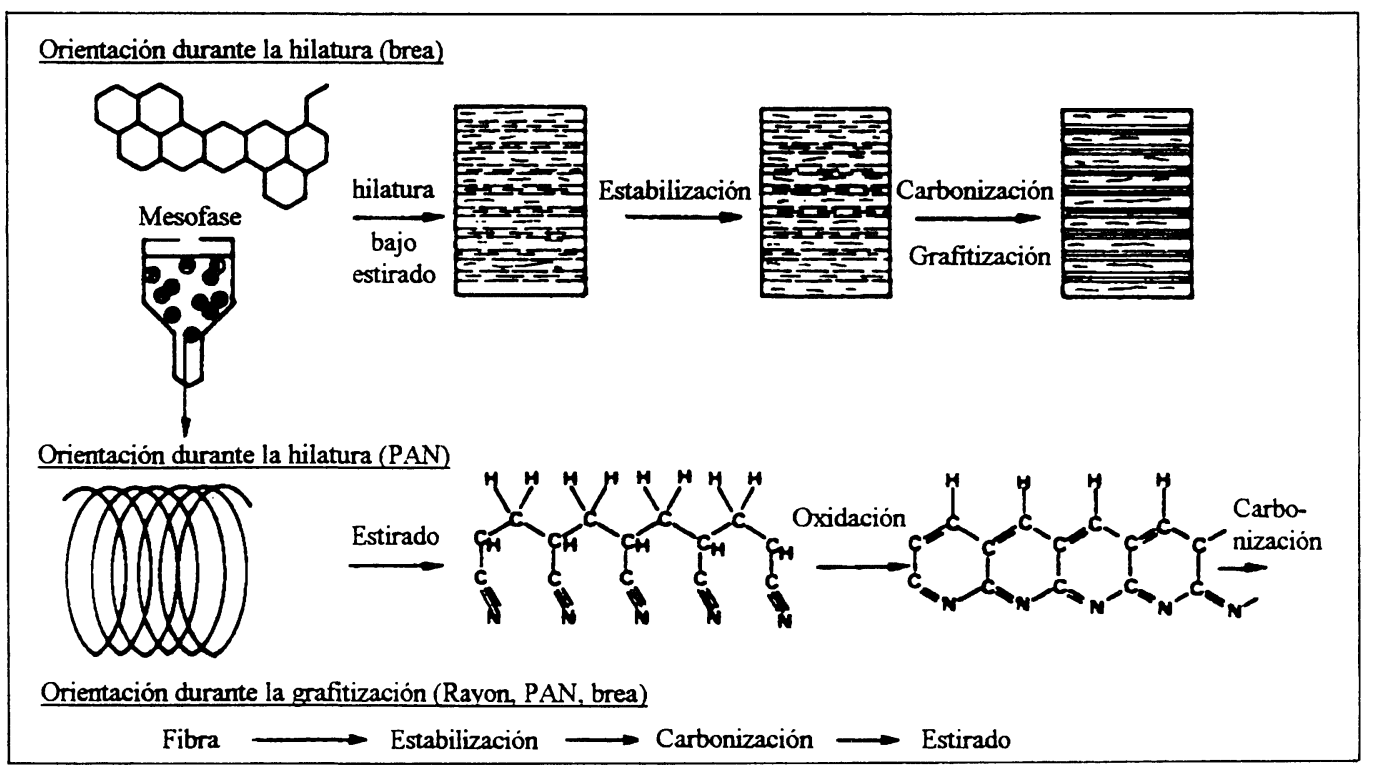

Figura 1.- Diagrama de los esquemas de carbonización para las mesofases de alquitrán y PAN.

Figure 1.- Diagram of carbonization schemes of pitch and PAN mesophases.

condiciones estáticas, sus propiedades son muy elevadas tanto en las fibras de alto módulo como en las de alta resistencia.

Su densidad es baja $\left(1,6 \mathrm{~kg} / \mathrm{dm}^{3}\right)$, lo cual implica que sus propiedades mecánicas específicas o por unidad de peso sean excepcionalmente elevadas.

Su coste, más elevado que el de las fibras de vidrio, está bajando drásticamente, debido al aumento de la demanda, al ser aplicado en numerosos sectores productivos además del aerospacial: deporte, transporte terrestre, marina, etc. Su incorporación junto con fibras de vidrio o aramida (materiales híbridos) presenta buenas expectativas, al presentar las tres fibras propiedades complementarias.

Entre las fibras de carbono de bajo coste de uso actual se pueden citar las siguientes: Fortafil $510-80 \mathrm{~K}$, Toray S 400-70K, Zoltek Panex 33-48K, Graphi 34-48K, Toray T700-24K, Toray T600-24K, Tenax HTS 5631$24 \mathrm{~K}$ y Tenax STS 5631-24K. Como se aprecia en la nomenclatura de estas fibras, las mechas están compuestas por un número muy elevado de filamentos, desde 24.000 hasta 80.000 , valores muy superiores a las mechas estándar que suelen tener entre 5.000 y 12. 000. Éste es el motivo del bajo coste. terms of static behavior, the mechanical properties are also very high for both high modulus and high strength carbon fibers.

The carbon fiber density is low $\left(1.6 \mathrm{~kg} / \mathrm{dm}^{3}\right)$, which means that its specific mechanical properties are exceptionally high.

The carbon fiber cost, superior than fiberglass, is drastically decreasing due to the demand increase in a number of industry sectors such as aerospace, sporting goods, ground transportation, marine, etc. Its implementation as hybrids in combination with fiberglass or aramid fibers present high expectations since their properties are complementary.

Among the low cost carbon fibers used currently, the following references are available: Fortafil 510-80K, Toray S 400-70K, Zoltek Panex 33-48K, Graphi 3448K, Toray T700-24K, Toray T600-24K, Tenax HTS 5631-24K and Tenax STS 5631-24K. As it can be seen from the nomenclature, the tows are composed by a large number of filaments ranging between 24.000 to 80. 000, higher values than aerospace grades which vary from 5.000 and 12.000. This is the reason for the low cost. 
Las fibras de carbono que tienen un módulo relativamente bajo ( $<70 \mathrm{GPa}$ ) y una baja resistencia a tracción $(<1 \mathrm{GPa})$, también son producidas a partir de alquitrán isótropo. Estas fibras de bajo módulo se pueden transformar en fibras de alto módulo mediante tracción de grafitización. Sin embargo, este método de fabricación es bastante costoso.

En las fibras altamente orientadas de alto módulo la estructura es grafítica, mientras que las de bajo módulo obtenidas a partir de alquitrán y las de módulo intermedio obtenidas a partir de rayón y de PAN tienen estructuras de grafito turboestrático. En el esquema de la Figura 2 se puede observar la estructura supermolecular de una fibra de módulo intermedio. El coeficiente de expansión térmica de estas fibras posee una notable variación no lineal con la temperatura. $\mathrm{La}$ conductividad térmica aumenta con el aumento de la perfección del cristal. Poseen una estabilidad relativamente baja a la termo-oxidación, pues el análisis termogravimétrico de las fibras de carbono en aire indica el comienzo de degradación entre los 500 y $700{ }^{\circ} \mathrm{C}$.

Los recubrimientos resistentes a la oxidación tales como el óxido de boro o el carburo de silicio se pueden aplicar sobre la superficie de la fibra de carbono si se desea una estabilidad más elevada a la termo-oxidación. En atmósfera inerte o en nitrógeno, estas fibras pueden soportar temperaturas mucho más elevadas. Pueden ser intercaladas con halógenos y con algunos metales álcalis como el $\mathrm{Na}, \mathrm{K}$, y Cs, para inducirle algún tipo de propiedad a las fibras como la conductividad eléctrica.

Para realizar modificaciones en la superficie de las fibras, se pueden utilizar tratamientos de plasma, tratamiento de oxidación en aire u oxígeno y tratamiento en ácido nítrico. Estas fibras también han sido encoladas con polímeros orgánicos como el polidivinilbenceno, poliamida, poliimida y organosiliconas. La técnica de implantación de un ion también se puede realizar con estas fibras para modificar su superficie.

Las fibras de carbono son anisótropas, incrementándose la anisotropía al aumentar el módulo axial. La estructura de las fibras de alto módulo obtenidas a partir de alquitrán es altamente grafitica (ordenamiento en forma de láminas), mientras que el ordenamiento en forma de láminas no se observa en las fibras obtenidas a partir de PAN o rayón.

\subsection{Tipos de fibras de carbono}

A partir de las temperaturas del tratamiento de calentamiento, se han identificado tres tipos diferentes de fibras de carbono:
The relatively low modulus carbon fibers $(<70 \mathrm{GPa})$ and low tensile strength $(<1 G P a)$, can also be produced form isotropic tar. These low modulus fibers can also be transformed in high modulus fibers by means of graphitization tension. However this method is very expensive.

The high modulus fibers are highly oriented and their structure is graphitic, while the low modulus obtained from pitch and medium modulus produced from rayon, their structure is turboestratic. The supermolecular structure of a medium modulus fiber is represented in Figure 2. The coefficient of thermal expansion (CTE) of carbon fibers presents a significantly non linear variation with the temperature. The thermal conductivity increases with the crystal perfection. They present a relatively low stability to thermal oxidation, since the thermogravimetric analysis of carbon fibers in air shows initiation of degradation between 500 and $700^{\circ} \mathrm{C}$.

The oxidation resistant coatings, such as boron oxide or silicon carbide can be applied on carbon fiber surface in order to obtain a higher stability to thermal oxidation. In inert atmosphere or nitrogen, carbon fibers bear much higher temperatures. They can be interleaved with halogens and several alkali metal such as $\mathrm{Na}, \mathrm{K}, \mathrm{y} \mathrm{Cs}$, to induce specific properties i.e. electric conductivity.

Plasma, oxidation in air and nitric acid treatments can be applied in order to modify surface properties on carbon fibers. These fibers have been adhered to organic polymers such as polydivinyl benzol, polyamide, polyimide and organic silicones. The implantation technique of an ion can also be applied to carbon fibers for surface modifications.

Carbon fibers are anisotropic, the anisotropy being proportional to the axial elastic modulus. The high modulus fibers produced from pitch present $a$ structure highly graphitic (laminated), while PAN or or rayon fiber structures are not laminated.

\subsection{Types of carbon fibers}

Three different types of carbon fibers can be defined in terms of heating treatment temperatures: 
. La fibra de alto módulo (HM) es la más rígida y requiere la mayor temperatura en el tratamiento.

- La fibra de alta resistencia (HR) es la más fuerte y se carboniza a la temperatura que proporciona la mayor resistencia a tracción.

. El último tipo de fibra (III) es la más barata; la rigidez es menor que en las anteriores pero la asistencia es buena. Este tipo tiene la temperatura más baja en el tratamiento.

\subsection{Propiedades}

Se distinguen por sus características específicas elevadas. Las fibras HM tienen un módulo específico 70 veces superior al de las aleaciones de aluminio (Tabla 1).

- Tienen un coeficiente de dilatación muy bajo, lo que permite una gran estabilidad dimensional a las estructuras y una conductividad térmica elevadas.

- Alta rigidez específica y gran resistencia.

- Tiene una resistencia a la fatiga asombrosa, la más elevada hasta ahora conocida.

. Su resistencia al roce es muy baja, lo que condiciona su manipulación.

- No presenta plasticidad, el límite de rotura coincide con el límite elástico

. Tienen los inconvenientes del coste: la baja resistencia al impacto de baja energía y las diferencias de potencial que engendran al contacto con los metales, que pueden favorecer corrosiones de tipo galvánico.
. High modulus (HM) is stiff and requires higher treatment temperatures.

. High strength $(\boldsymbol{H R})$ is the strongest and is carbonized at the temperature associated to the highest tensile strength.

. The third type (III) is the lowest cost, its stiffness is lower than is previous types but the strength is high, this type is treated at temperatures lower than HM and $H R$ fibers.

\subsection{Properties}

The main characteristic is the high specific mechanical properties. HM fibers present a specific modulus 70 times higher than alloys (Table 1).

Low coefficient of thermal expansion, which means high dimensional stability and thermal conductivity.

\section{High specific stiffness and strength.}

Exceptionally high fatigue strength.

\section{Low friction strength.}

- Does not present plasticity, the failure limit coinciding with the elastic one.

- As drawbacks, the following facts are mentioned: reduced low energy impact strength, potential differences with in contact with metals, which means galvanic type corrosion and high cost.

TABLA $1 /$ TABLE 1

Propiedades de diferentes fibras de carbono provenientes de PAN (Properties of PAN fibers)

\begin{tabular}{|c|c|c|c|}
\hline $\begin{array}{l}\text { Designación } \\
\text { (Designation) }\end{array}$ & $\begin{array}{l}\text { Alta resistenica (HR) } \\
\text { (High strength }(H R) \text { ) }\end{array}$ & $\begin{array}{l}\text { Alto módulo (HM) } \\
\text { (High modulus (HM) }\end{array}$ & III \\
\hline $\begin{array}{l}\text { Diámetro de hilo }(\mu \mathrm{m}) \\
\text { (Diameter of filament }(\mu \mathrm{m})\end{array}$ & 8 & 7 & $7-8$ \\
\hline $\begin{array}{l}\text { Densidad }\left(\mathrm{kg} / \mathrm{m}^{3}\right) \\
\left(\text { Density }\left(\mathrm{kg} / \mathrm{m}^{3}\right)\right)\end{array}$ & $1740-1760$ & 1820 & 1820 \\
\hline $\begin{array}{l}\text { Módulo de elasticidad (GPa) } \\
\text { (Elasticity modulus (GPa)) }\end{array}$ & 230 & 390 & 290 \\
\hline $\begin{array}{l}\text { Resistencia a tracción (GPa) } \\
\text { (Tensile strength }(G P a))\end{array}$ & $2,6-5$ & $2,1-2,7$ & 3,1 \\
\hline $\begin{array}{l}\text { Elongación a la rotura (\%) } \\
\text { (Elongation of failure (\%)) }\end{array}$ & 2 & 0.7 & 1,1 \\
\hline $\begin{array}{l}\text { Módulo específico } \\
\text { (Specific modulus) }\end{array}$ & 130 & 210 & 160 \\
\hline $\begin{array}{l}\text { Coeficiente expansión térmica } \\
\left(10^{-6} /{ }^{\circ} \mathrm{C}\right) \\
\text { (Coefficient thermal expansion } \\
\left(10^{-6} \mathrm{PC}\right)\end{array}$ & 2,56 & 2,56 & 2,56 \\
\hline
\end{tabular}




\subsection{Fabricación de las fibras de carbono}

Las fibras de carbono se fabrican mediante pirólisis controlada y ciclización de precursores de cierta fibra orgánica, el más común de los cuales es el precursor poliacrilonitrilo $(P A N)$ y el alquitrán; el primero es una fibra sintética y el segundo se obtiene de la destilación destructiva del carbón. Existe otro precursor de fibra de carbono que se deriva de materiales provenientes de la celulosa, el rayón (Figura 2).

Precursores de rayón, como se ha comentado se derivan de materiales provenientes de la celulosa. Actualmente apenas se utilizan, debido a que en el proceso de fabricación, al llegar a la carbonización, se pierde un $75 \%$ de la masa de fibra y resulta un proceso mucho más caro que el resto.

Precursores de alquitrán, basados en MPP, en brea o en cloruro de polivinilo (PVC). Las fibras de carbono que derivan de estos precursores son relativamente más baratas ya que tienen una transformación más efectiva que los anteriores precursores.

Precursores PAN, ya se ha dicho que son la base para la mayoría de las fibras comerciales en la actualidad. La conversión en fibra de carbono al final del proceso de transformación, está entre el 50 y el 55\% (Figura 3).

Cada tipo de precursor tiene su técnica de procesado pero en general todos siguen una misma secuencia, tomando como base un proceso de fabricación cuyo precursor es el PAN, se pueden distinguir las siguientes etapas: estabilización, carbonización, grafitización y tratamiento de superficie.

A) Estabilización. En el primer paso de la fabricación de la fibra de PAN (estabilización), un filamento de

\section{Manufacturing of the carbon fibers}

Carbon fibers are produced by controlled pyrolysis of precursors such as PAN obtained form a synthetic fiber and pith as a result of carbon distillation. The rayon, which is derived from the cellulose, is less utilized (Figure 2).

Rayon precursor, is barely used due to the $75 \%$ mass loss along the process and the manufacturing costs.

Pitch precursor, based on MPP, pith or polyvinyl chloride. Carbon fibers obtained form this precursor is relatively lower cost since the higher manufacturing efficiency.

$P A N$ precursor, is the most used nowadays. The efficiency of the process is in the range between 55 and $50 \%$, the rest of the mass id lost along the process (Figure 3).

Every precursor type has its own manufacturing technique but the three of them follow the same sequence. Taking the PAN precursor manufacturing process as a reference the following step can be differentiated: stabilization, carbonization, graphitization and surface treatment.

A) Stabilization. In this first step, the filament of PAN copolymer is stretched and heated along an
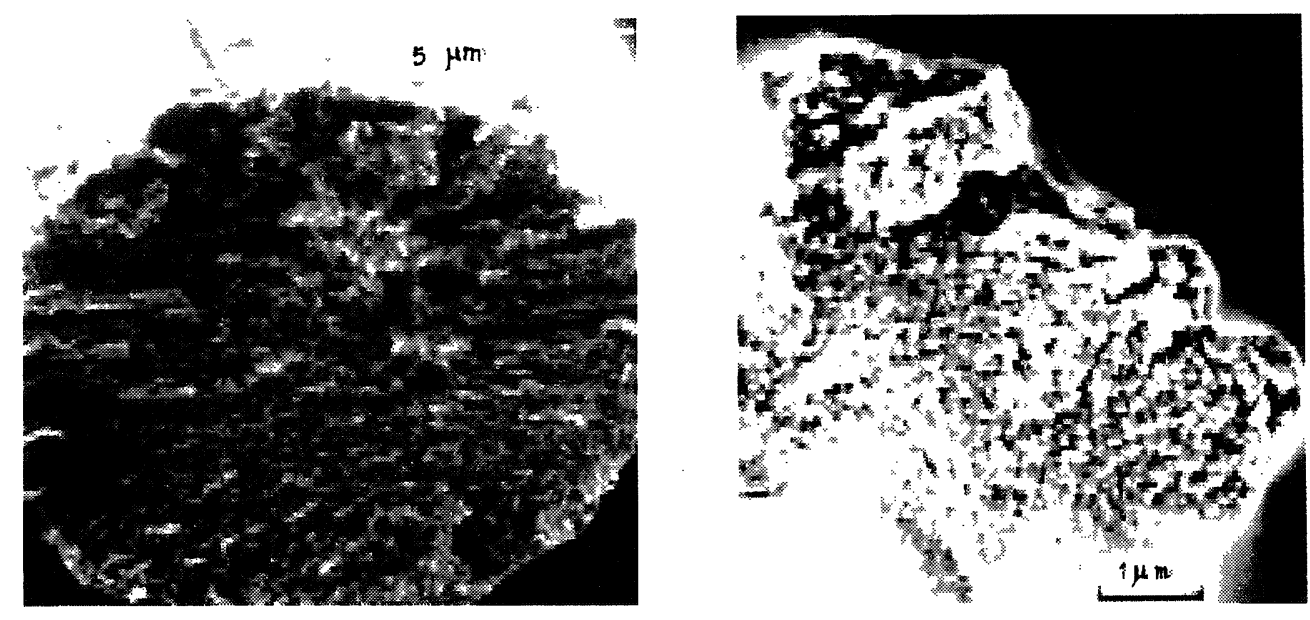

Figura 2.- Fibra de carbono proveniente de precursor del alquitrán.

Figure 2.- Pitch precursor carbon fiber. 

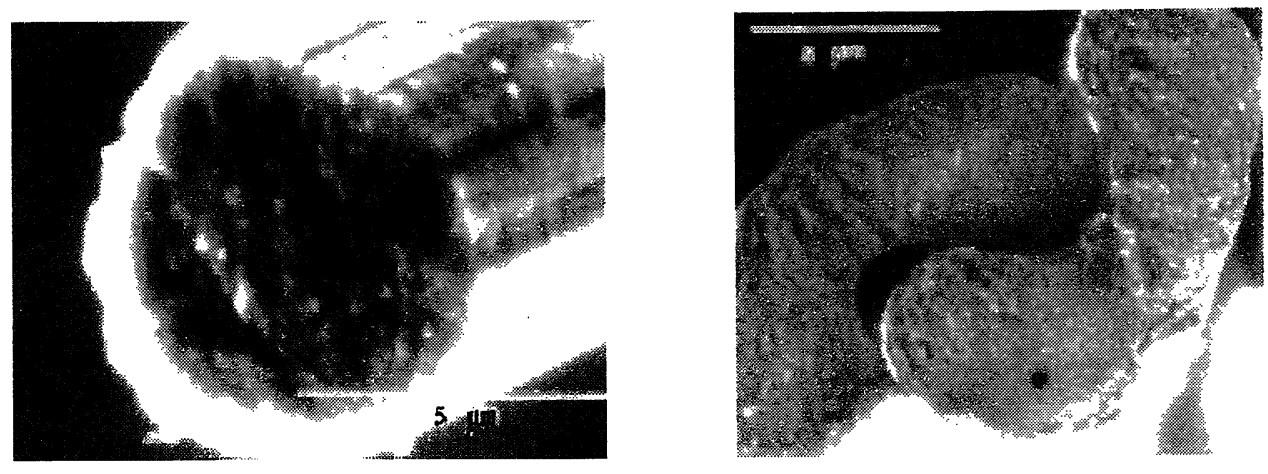

Figura 3.- Fibra de carbono proveniente de precursor PAN.

Figure 3.- PAN precursor carbon fiber.

copolímero de poliacrilonitrilo (PAN) es estirado y pasado a través de un horno de oxidación a baja temperatura para adquirir estabilidad dimensional. Este paso suele denominarse infusible.

B) Carbonización. En el siguiente paso de carbonización la estructura interna del polímero se convierte a una alta temperatura más alta $\left(800^{\circ} \mathrm{C}\right.$ bajo una atmosfera inerte) en lazos de anillos hexagonales de carbono continuo. Durante el período de calentamiento, muchos elementos diferentes del carbono desaparecen y los cristales de carbono se orientan a lo largo de toda la longitud de la misma.

C) Grafitización. En el siguiente tratamiento de calentamiento a más altas temperaturas por encima de $2000^{\circ} \mathrm{C}$ (grafitización), el tamaño de los cristales de carbono aumenta y mejora la orientación de los cristales de la fibra.

D) Tratamiento de superficie. Finalmente, la fibra pasa a través de una cámara de tratamiento de superficie para promover la adhesión de la fibra.

Otros pasos serían el acabado y el empaquetado, en función de la presentación industrial, para facilitar el manejo de la fibra.

Los pasos de procesamiento para la fibra de precursor de alquitrán son similares, salvo en el paso inicial, en el que la fibra se derrite a partir de alquitrán procesado isótropo o anisótropo. El tamaño y orientación de los cristales, la porosidad de la fibra y su impureza son los principales factores que afectan a las propiedades físicas finales del filamento.

Cuando el tratamiento de calentamiento para la fibra de carbono aumenta, el módulo de elasticidad crece exponencialmente a lo largo de todo el rango de temperatura; el motivo es que la cristalinidad de la fibra aumenta hasta un valor máximo hacia los $1.600^{\circ} \mathrm{C}$ y oxidation furnace to obtain dimensional stability.

B) Carbonization. In this step, the internal structure of the polymer is transformed in lazes of hexagonal ring of continuous carbon, the temperature reaching $800{ }^{\circ} \mathrm{C}$ under an inert atmosphere. During this heating period, many different elements in the carbon system disappear and carbon crystals are oriented along the length of the polymer.

C) Graphitization. The size of the crystals increases and the orientation is improved along this heating treatment up to temperatures higher than $2000{ }^{\circ} \mathrm{C}$ (graphitization).

D) Surface treatment. Finally, the fiber is conducted through a surface treatment chamber to easy the adhesion of the fiber to the matrix.

Other additional steps are the finishing and packaging, depending of the industrial presentation required.

The steps for a pith fiber production would be similar to the one described for the PAN fiber, except for the first step, where the fiber is melt from the processed pith. The size and orientation of the crystals, the fiber porosity and its imperfections are the main factors to obtain the mechanical properties of the filaments.

When the heating treatment temperature increases, the elastic modulus present higher values following and exponential law up to a maximum value of 
entonces cae hasta un valor constante, mientras la temperatura sube hasta el valor más alto utilizado.

\subsection{Presentaciones industriales de la fibra de carbono}

Son disponibles en diversas presentaciones:

\author{
. Mechas (500-100.000 filamentos) y Roving \\ (Figura 4)..
}

- Tejidos (unidireccionales o multidireccionales) (Figuras 5 y 6).

. Preimpregnados con resina epoxi.

\subsection{Aplicaciones a la construcción}

\subsubsection{Reparaciones y refuerzos anti-sísmicos}

Las láminas metálicas adheridas al hormigón mediante resina de epoxi se utilizan desde hace cuarenta años. Sin embargo, la lámina metálica presenta serios problemas como tales como la vulnerabilidad a la corrosión, requiere pintura de protección, inspección periódica y operaciones de mantenimiento, la superficie a reparar debe ser plana (Figura 7).

La capa del adhesivo debe ser muy uniforme, lo cual implica tratamiento de superficie y un estricto control de calidad antes de la aplicación del adhesivo, es frecuente la presencia de burbujas cuando se aplica la
$1.600{ }^{\circ} \mathrm{C}$, dropping since this point to a low value, where the modulus remains constant.

\subsection{Industrial presentations}

The following presentations are industrially available:

\section{. Tows (500-100.000 filaments) and Roving}

(Figure 4).

- Fabrics (unidirectional o multiaxial)

Figures 5 and 6)

- Prepregs with epoxy resins

\subsection{Applications to the building industry}

\subsubsection{Repairing and reinforcing structures}

Sheet-bonded metal repair jobs have been used for the last forty years. However, sheet metal cumulates a number of certain number of disadvantages such as a vulnerability to corrosion, it requires paint for protection, followed by regular inspection and maintenance work and the sheets can be applied only to perfectly flat surfaces (Figure 7).

The adherent layer must be uniform, which means a great deal of surface treatment work on the substrate, and a strict inspection before beginning any work. Another consideration is that it is complicated to avoid the presence of air bubbles when the sheet metal is being applied onto the substrate, and this reduces the

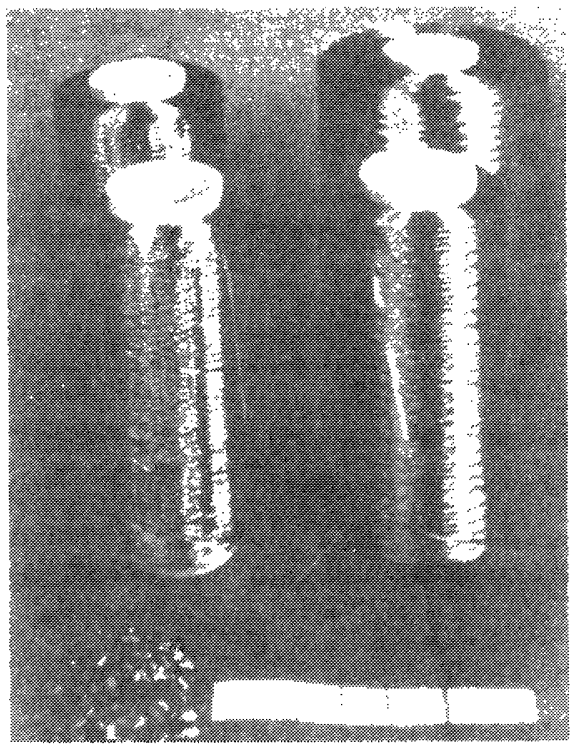

Figura 4.- Rowing de carbono.

Figure 4.- Rowing of carbon. 

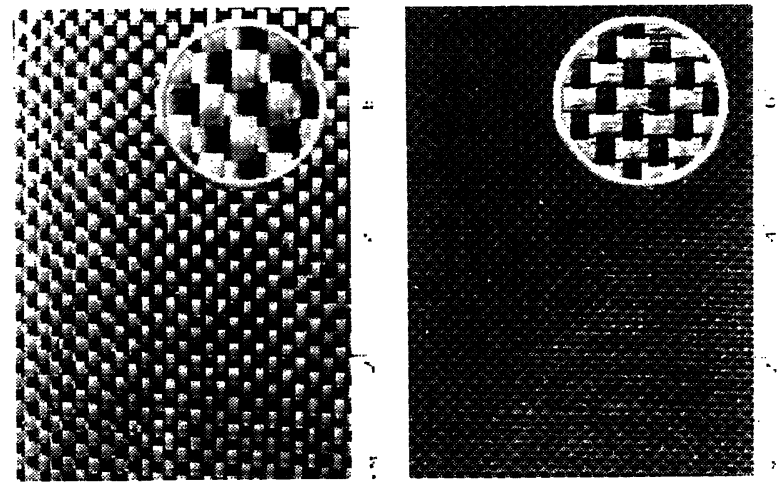

Figura 5.- Tejidos de carbono con diferentes ppi (punzadas por "inch") y, por tanto, diferente tamaño de mecha.

Figure 5.- Fabrics with different ppi (punctures per "inch"), and therefore different size of tows.

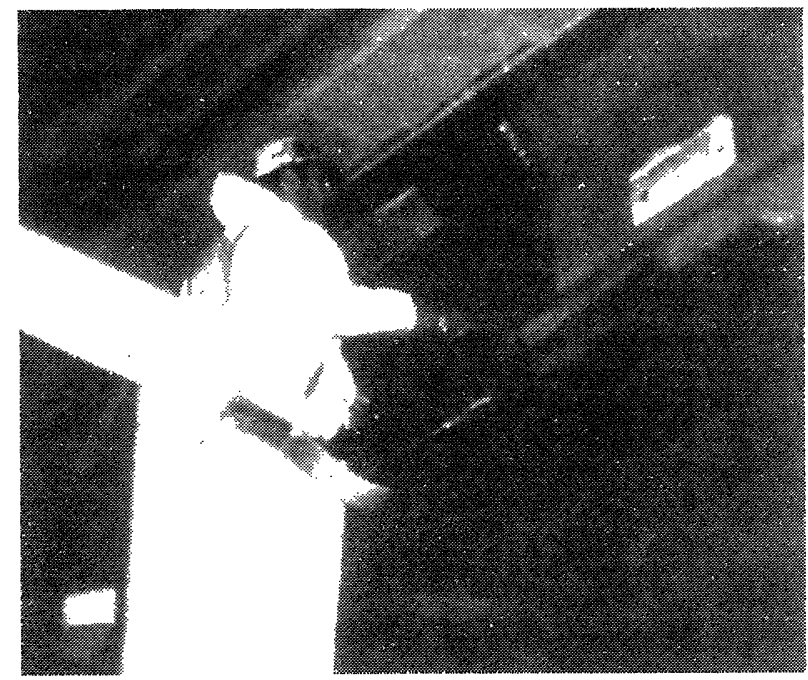

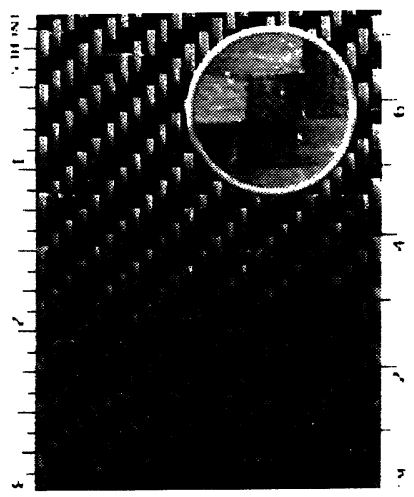

Figura 6.- Tejido de carbono híbrido carbono-aramida.

Figure 6.- Fabric of hybrid carbon-aramid.

Figura 7.- Reparación de una viga de hormigón de un puente. Estas reparaciones se realizan con preimpregnado de carbono/ epoxi adheridos a la superficie de la viga.

Figure 7.- Repair of a concrete beam in a bridge. The cured carbon fiber/epoxy resin plate has been uded in this case.

lámina metálica lo cual reduce el rendimiento de la unión, para ello se suelen taladrar las láminas de metal lo cual aumenta el coste y reduce drásticamente la resistencia mecánica de la lámina. Las láminas están sometidas a flexión, de modo que cuanto más gruesa es la lámina menor es la resistencia debido a los efectos laterales, estando limitado el espesor de la lámina a $5 \mathrm{~mm}$.

Por otra parte, el metal es pesado y poco eficiente para el transporte y la manipulación, siendo necesaria la aplicación de una presión elevada hasta que la resina de epoxi ha completado su proceso de curado. La posibilidad de solicitaciones de impacto sobre la lámina metálica una vez que la reparación está operativa es un problema que suele resolverse mediante el anclaje por medio de uniones mecánicas entre el metal y el hormigón aumentando el coste y el tiempo de ejecución de la reparación.

Existen fundamentalmente dos técnicas de reparación de estructuras de hormigón: efficiency of the bonding. To avoid this problem, perforated sheets are used so that the excess of resin may be evacuated. However, this solution not only increases cost but also reduces mechanical strength of the joint. The sheets are subjected to flexure loads, the thicker the sheets, the less they are able to withstand the loads, because of this side effect, sheet thickness is limited to a maximum $5 \mathrm{~mm}$.

On the other hand, metal sheets are heavy and difficult to transport and handle. They must be subjected to a careful degreasing process to ensure that the resin will be bonded to the sheet. The possibility of impact loadings over the metal sheet once the repair is on operation is a problem that can be solved fastening the sheet metal with bolts anchored in the concrete with the corresponding increase of cost and duration of the repair procedure.

Basically, there are two repairing procedures over concrete structures: 
- Aplicación de una lámina de fibra de carbono y resina de epoxi endurecida previamente. Las superficies irregulares presentan limitaciones debido al carácter endurecido del material compuesto. Normalmente las dimensiones de las placas son las siguientes:

\section{. Espesor: 1 a $2,5 \mathrm{~mm}$}

. Anchura: 25 a $120 \mathrm{~mm}$

- Impregnación de la fibra de carbono con resina de epoxi en obra. En este caso, el control de calidad es crítico debido a la necesidad de combinar en húmedo la resina con la fibra de carbono.

Existen en el mercado numerosos productos comerciales que se ajustan a las dos técnicas mencionadas. Ambas tienes ventajas e inconvenientes. En superficies planas, se aplica mayoritariamente la lámina curada mientras que en geometrías curvadas, como, por ejemplo, el refuerzo de columnas para cargas sísmicas se utiliza la impregnación en húmedo en obra (Figura 8).

En los últimos años se han implantado numerosas tecnologías textiles -fundamentalmente fabricadas mediante "weaving"- con objeto de optimizar la preforma de fibra de carbono a impregnar con la resina en obra.

\subsubsection{Puesta en obra}

Se ha comentado en la introducción de este artículo
- Application of a carbon fiber lepoxy plate previously cured over the concrete surface. The irregularities on the concrete surface can be a problem due to the solid nature of the carbon fiber plate. Usually the plate dimensions are the following:

\section{. Thickness: from 1 to $2.5 \mathrm{~mm}$ \\ .Width: from 25 to $120 \mathrm{~mm}$}

. In situ impregnation of carbon/fiber and epoxy resin. The quality control is critical in this case due to the need to impregnate the fiber in wet resin.

There are a number of commercial products available in the market corresponding to the two techniques above described. Both have pros and cons. The cured plate is most used when working with flat surfaces, while the wet method is used in curved applications, such as the reinforcements of column (Figure 8).

For the last years, several textile technologies -mostly weaving manufactured preforms- with the aim of optimizing the carbon fiber preform to be impregnated in-situ with the epoxy resin.

\subsubsection{Use a a material building}

The implementation of carbon fiber as a building



Figura 8.- Refuerzo anti-seismos de pilares de hormigón de puentes. Se realiza un embandado de los pilares con vidrio, vidrio/aramida y carbono sobre resina de epoxi con objeto de aumentar la resistencia sísmica del puente y alargar su vida útil.

Figure 8.- Reinforcements of columns in a bridge. The glass/aramid and carbon fibers are winded and impregnated with epoxy resin with the objective of reinforcing the columns under seismic loadings, increasing the life of the structure. 
que la implantación en la obra civil esta avanzando más despacio que la utilización en reparaciones debido al bajo coste de los materiales tradicionales, a la limitación de procesos de fabricación de estructuras de materiales compuestos y al conservadurismo de las normativas de edificación y obra civil en todos los países industrializados.

Sin embargo, los tres asuntos mencionados están siendo abordados con eficiencia obteniéndose los primeros resultados interesantes en la ejecución de puentes para vehículos de luces bajas así como en cubiertas de edificios y obras singulares.

Se espera que la reducción monótona de los costes de la fibra de carbono, la puesta a punto y reducción de costes de procesos tales como SCRIMP, moldeo por transferencia de resina, infusión y la introducción de nueva normativa en materiales compuestos para la construcción constituyan los principales pilares para el desarrollo de esta industria y la producción de fibra de carbono aumente en 25 veces en los próximos diez años. Se pueden distinguir dos campos principales de aplicación: puentes y edificicación.

\subsubsection{Puentes}

En la actualidad, se está comenzando a implantar fibra de carbono como elemento estructural en puentes convencionales con tráfico de vehículos en dos líneas diferentes:

- La utilización de parrilla de fibra de carbono que refuerzan al hormigón y sustituyen al armado metálico. Estas parrillas son construidas en varias fases. En primer lugar se realiza el trenzado de la fibra mediante un procedimiento automotizado de "weaving", a continuación se impregna con la matriz orgánica, quedando el material compuesto conformándose sobre un molde flexible, finalmente se aplica presión y calor para conseguir el curado del material. Existen otros procedimientos tales como el moldeo por transferencia de resina y la pultrusión.

Un ejemplo de esta tecnología es el puente en Rollingsford en New Hampshire, EE UU (Figura 9). El tablero está formado por hormigón reforzado con parrillas de fibra de carbono, no se ha utilizado ni un gramo de acero. Ochenta sensores de fibra óptica embebidos en el tablero permitirán monitorizar el estado del puente durante su vida útil.

Otro ejemplo es puente sobre el río Assiniboine en Winnipeg en el estado de Manitoba, Canadá de 165 metros de longitud. En la Figura 10 se aprecian las parrillas de carbono antes de colar el hormigón. Este puente también está monitorizado mediante sensores de fibra óptica. material is being increased with a rate lower than repair and reinforcing concrete structures due mainly to the low cost of traditional building materials, the limitation of composite structure manufacturing technologies and the conservative building regulations in the industrialized countries.

However, the three issues mentioned in the above paragraph are being efficiently faced, obtaining interesting results in low-span bridges for vehicles, building roofs and singular structures.

A high development of the carbon fiber in the building industry in the coming years is expected due to the monotonic cost reduction of carbon fibers, setting up of low-cost composite manufacturing processes such as scrimp, RTM, infusion and finally, the implementation of new regulations specific for composite materials

\subsubsection{Bridges}

Currently, carbon fiber structures are being used for bridges following two mainstreams:

\section{- Using of carbon fiber grids to reinforce the} concrete and substituting the metallic bars. These grids are manufactured, weaving the fiber following an automated process, impregnation over a flexible mold and finally applying pressure and heating to cure the composite material. There are also alternative processes such as resin transfer molding (RTM) and pultrusion

An application of this technology can be shown in the bridge in Rollingsford (New Hampshire), USA (Figure 9). The deck is composed of concrete reinforced with carbon fiber grids. Eighty optical fiber sensors are embedded in the deck to monitor the long term behavior.

Another application is the 165 meter span bridge over the Assiniboine river in Winnipeg (Manitoba), Canada. The carbon fiber grids before being embedded in the concrete can be seen in Figure 10. This bridge is also being monitored. 


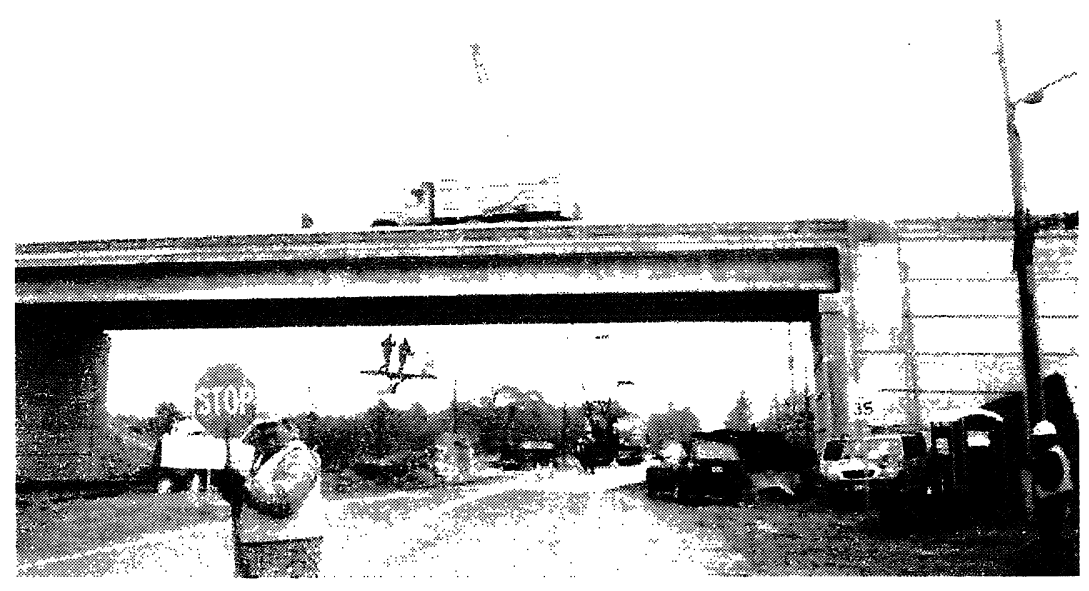

Figura 9.- Puente en Rollingsford en New Hampshire, EE UU.

Figure 9.- Bridge in Rollingsford in New Hampshire, USA.

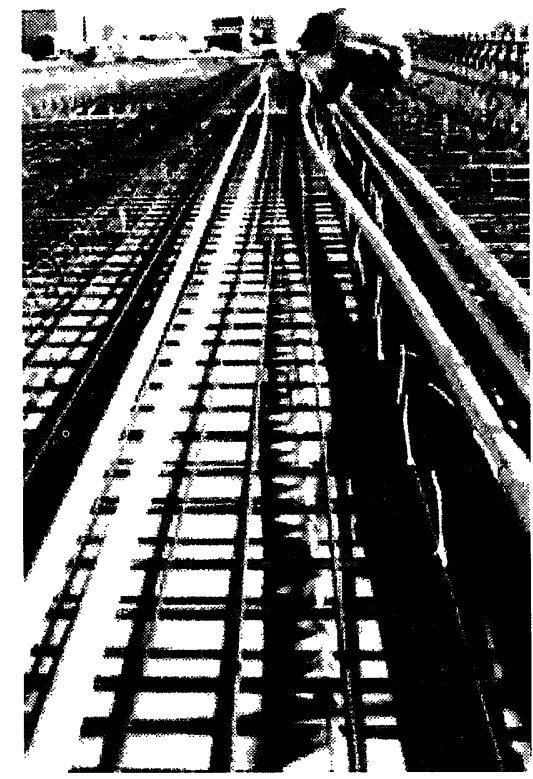

Figura 10.- Puente sobre el río Assiniboine en Winnipeg en el estado de Manitoba, Canadá.

Figure 10.- Bridge over Assiniboine river in Winnipeg (Manitoba), Canadá.

- La implantación de perfiles de pultrusión de fibras de carbono o híbridos carbono/vidrio. Se está aplicando durante más de dos décadas perfiles de pultrusión para puentes peatonales y para vigas transversales de puentes para vehículos. En la actualidad se están implantando perfiles de pultrusión longitudinales configurando el tablero del puente.

Para ello, se fabrican vigas de 0,91 metros de altura y 45,7 metros de anchura (Figura 11). Estas vigas

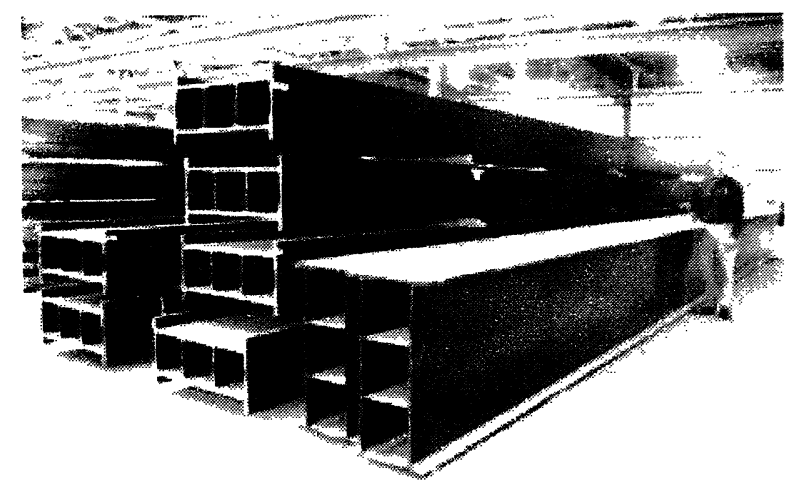

Figura 11.- Vigas de fibra de carbono de 0,91 metros de canto fabricadas mediante pultrusión.

Figure 11.- 0.91 meter high carbon fiber pultruded profiles.

. Implementation of carbon fiber or hybrids as pultruded profiles. This technique is being applied for the last two decades for pedestrian bridges and transverse beams in short span vehicle bridges. Currently, deck longitudinal beams are being built with pultruded profiles.

0.91 meter high and 0.457 meter width carbon fiber pultruded profiles (Figure 11) are being manufactured 
incorporan dos rigidizadores para evitar pandeo de las almas en el propio proceso de pultrusión. Un ejemplo de esta aplicación es el puente en Lake Jackson (Texas, EE UU) de 32 metros de longitud en dos tramos. Se dispusieron dos vigas de en cada tramo.

\subsubsection{Edificación}

La fibra de carbono se utiliza de forma creciente en aquellas aplicaciones constructivas donde se requiere gran resistencia estructural y bajo peso. Existen numerosos ejemplos de aplicaciones. Uno muy conocido es el tablero de suelo de la zona de reptiles del Zoo de Amberes, Bélgica (Figura 12).

El citado tablero precisaba una resistencia de $1.500 \mathrm{~kg} / \mathrm{m}^{2}$ y está fabricado en estructuras sándwich con pieles de fibra de carbono. Existen otras aplicaciones como por ejemplo cubiertas estructurales, como es el caso del edificio comedor de Toray (Japón).

Otro campo de aplicación de interés creciente son los edificios singulares donde predomina el trazado con curvaturas. Es una cuestión del tiempo que la fibra de carbono se imponga sobre el resto de materiales estructurales debido a la moldeabilidad, resistencia y ligereza del material. Una aplicación en esta línea es el Museo de Arte de Milwaukee, diseñado por Santiago Calatrava (Figura 13). La construcción consiste en 36 parejas de timones de fibra de carbono conectadas a dos ejes de acero giratorios anclados a la estructura fija. Este sistema esta diseñado para abrirse y cerrarse como las alas de un pájaro de dimensiones gigantes en 3,5 minutos. Los timones de fibra de carbono tienen longitudes variables entre 8 y 32 metros, anchos de 0,6 a 1,2 metros y espesores de 0,3 metros. for bridge deck applications. These profiles incorporate two transverse stiffeners to avoid web buckling. Un application of this technology can be seen in the 32 meter span bridge in Lake Jackson (Texas, USA). The deck is composed of two parts, incorporating each part two pultruded beams.

\subsubsection{Buildings}

Carbon fiber is increasing used in those applications where high strength and low weight are the main requirements. There are a number of applications where carbon fiber has been used as a building material. A very well know structure is the deck floor in Atwerpen Zoo's reptile hall (Figure 12).

This floor required a $1.500 \mathrm{~kg} / \mathrm{m}^{2}$ strength and it has been manufactured with sandwich panels with carbon fiber skins. There are other applications such as the roof of the cafeteria in the Toray factory, in Japan.

Another application field with increasing interest is the singular structures where the curvatures are critical due to esthetic reasons. It is a matter of time that the carbon fiber will impose over traditional materials due to its capability to adopt any shape, strength and lightness. A unique sunscreening structure on the new building housing the Milwaukee Art Museum addition will incorporate carbon fiber as structural parts, designed by Santiago Calatrava (Figure 13).The construction will consist of 36 pairs of carbon fiber spines attached to a central hub. This system has been designed to open and close in 3.5 minutes like the wings of a giant bird to shade the museum's sail-shaped glass and steel skylight. The carbon fiber fins present variable lengths ranged between 8 and 32 meters, widths between 0.6 and 1.2 meters and thickness of 0.3 meters.

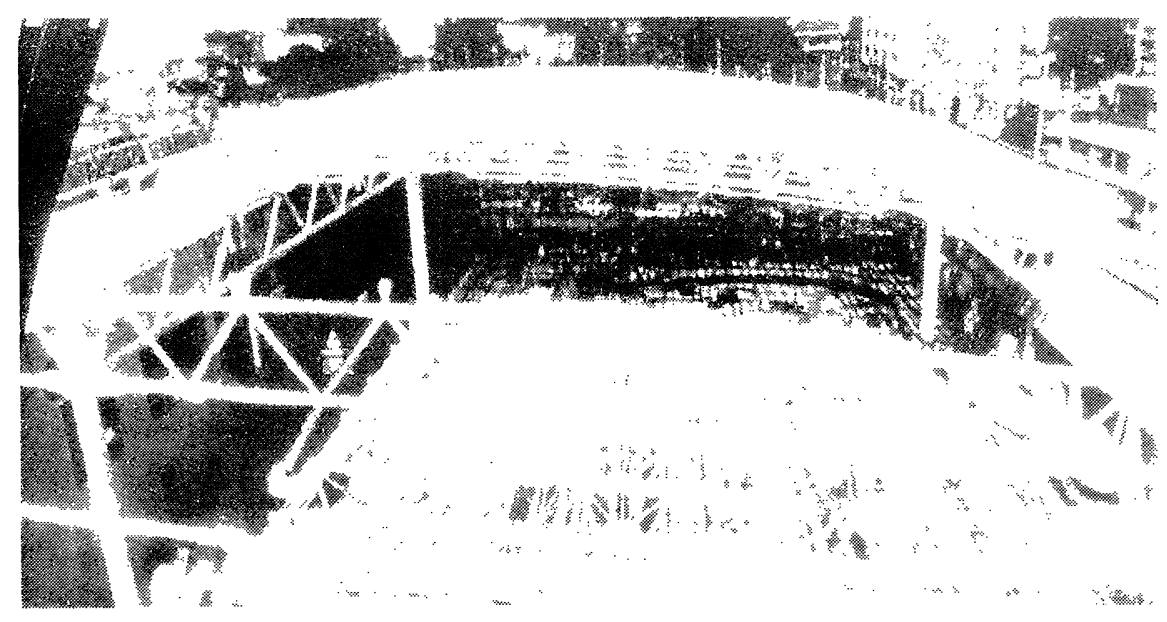

Figura 12.- Tablero de suelo de la zona de reptiles del Zoo de Amberes, Bélgica.

Figure 12.- Deck floor in Atwerpen Zoo's reptile hall in Belgium. 


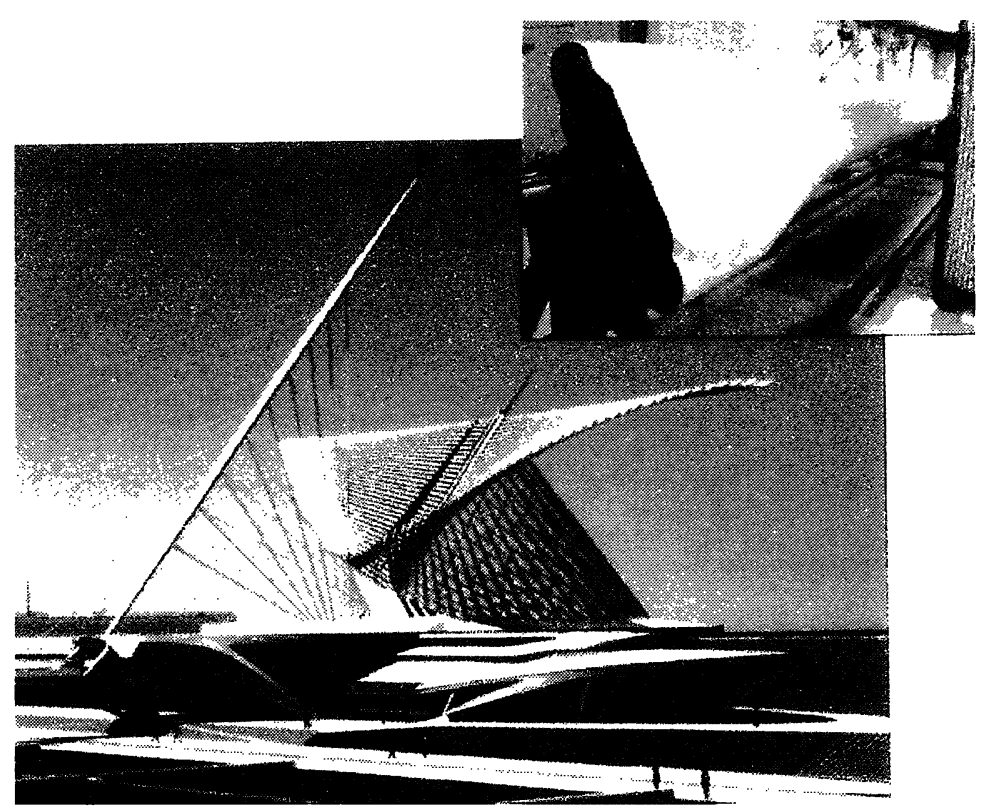

Figura 13.- Museo de Arte de Milwaukee y detalle de timón fabricado en fibra de carbono.

Figure 13.- The new building housing the Milwaukee Art Museum.

\section{LA FIBRA DE CARBONO COMO SENSOR DE CARGA}

La Universidad de Buffalo en el estado de Nueva York está trabajando en un nuevo material formado por hormigón coñ un $0,5 \%$ de fibra de carbono especialmente tratada que aumenta la conductividad eléctrica del hormigón.

Los experimentos llevados a cabo revelan que al aplicar una carga sobre este nuevo material reduce la efectividad del contacto entre cada fibra y el hormigón que le rodea disminuyendo ligeramente su conductividad eléctrica. Al descargar el material, el hormigón recupera su conductividad original. Este material puede utilizarse como estructural y como sensor simultáneamente.

Si se aplica este material como firme de carretera o sobre un puente, se obtendrá información sobre los vehículos que circulan, al medir las fluctuaciones de la conductividad, calibrando esta propiedad se podrá determinar la magnitud de la carga sobre el firme. Podría utilizarse en el futuro como sistema de almacenamiento de datos de tráfico.

Puede también explotarse para hacer del hormigón un reflector de las radio-ondas y así obtener un escudo electromagnético, este concepto podría aplicarse a la edificación, diseñando edificios cuyas paredes impidieran el paso de las ondas electromagnéticas.

\section{THE CARBON FIBER AS LOAD SENSOR}

The University of Buffalo in New York, USA is working on a new material composed of concrete with $0.5 \%$ of carbon fiber specially treated to increase the electric conductivity of the concrete.

The experiments carried out reflect that when applying a mechanical load on this new material, the efficiency of the contact carbon fiber-concrete decreases, and therefore the electric conductivity of the material is reduced. When unloading, the concrete gets back its original conductivity. This material can be used as both structural and sensor system simultaneously.

If this carbon fiber/concrete is used as pavement or bridge deck material, conductivity fluctuations can be measured. By calibrating the smart concrete prior to the testing, the researchers would be able to determine the relationship between resistance and weight, and therefore useful information about the vehicles passing over could be obtained.

This material can also be used as radio-wave reflector, obtaining an electromagnetic shield. This concept could be applied to building whose walls stopping the electromagnetic waves from outside. 
Tiene, asimismo, aplicaciones para el guiado de automóviles sin conductor, aprovechando las propiedades reflectoras de radio-ondas.

La implicación de la variación de conductividad eléctrica en la temperatura puede tener ventajas en aplicaciones de sistemas de calefacción y deshielo de carreteras haciendo pasar una corriente de bajo voltaje a través del hormigón.

Finalmente, puede utilizarse como material conductor para iluminación.

En definitiva, existe una larga lista de posibles aplicaciones de nuevos materiales en la construcción con propiedades de gran interés tecnológico y muy distintas de los sistema que lo componen, la clave de los materiales compuestos modernos.
Automated cars without driver could be guided through this material, taking advantage of its properties as radio-wave reflector.

The relationship between the electric conductivity and temperature can also be exploited in heating and thaw applications, passing a low voltage current through the smart concrete.

Finally, this material system can be used as conductor for lighting.

As a conclusion, there are a large number of potential applications with high tech properties, very different to the materials that compose the smart concrete, they key issue of the modern composite materials.

\section{BIBLIOGRAFÍA}

(1) "Materiales Compuestos" Editado por Antonio Miravete. Zaragoza, 2000.

(2) Miravete, A. «Documentación de las I Jornadas de Materiales Compuestos». Ingeniería de Materiales Compuestos. Zaragoza 2022 enero, 1988

(3) Miravete, A. «Documentación de las II Jornadas de Materiales Compuestos». Ingeniería de Materiales Compuestos. Zaragoza 2325 mayo, 1990.

(4) Miravete, A. «Documentación de las III Jornadas de Materiales Compuestos». Ingeniería de Materiales Compuestos. Zaragoza 30 marzo-3 abril, 1992.

(5) Miravete, A. «Documentación de las IV Jornadas de Materiales Compuestos». Ingenieria de Materiales Compuestos. Zaragoza 1114 abril, 1994

(6) Miravete, A. «Documentación de las V Jornadas de Materiales Compuestos». Ingeniería de Materiales Compuestos. Zaragoza 2629 junio, 1995 .

(7) Miravete, A. «Documentación de las VI Jornadas de Materiales Compuestos». Ingeniería de Materiales Compuestos. Madrid 1517 abril, 1996.

(8) Miravete,A. «Documentación de las VII Jornadas de Materiales Compuestos». Ingeniería de Materiales Compuestos. Zaragoza 24 junio, 1996.

(9) Miravete,A.«Documentación de las VIII Jornadas de Materiales Compuestos». Ingeniería de Materiales Compuestos. Zaragoza 1516 febrero, 1999.

(10) Miravete,A. «Documentación de las IX Jornadas de Materiales Compuestos». Ingeniería de Materiales Compuestos. Zaragoza $12-$ 13 junio, 2000.

(11) «Engineered Materials Handbook, Volume 1. Composites». ASM International, 1987.

(12) «Engineered Materials Handbook, Volume 2. Engineering Plastics». ASM International, 1988

(13) Antequera, P., Jiménez, L., Miravete, A. «Los materiales compuestos de fibra de vidrio». Edita Secretariado de publicaciones de la Universidad de Zaragoza, 1991

(14) Miravete, A. "Los nuevos materiales en la construcción». Edita A. Miravete, 1994.

(15)«Handbook of Composites». Edita George Lubin, 1982.(

(16) Mallick, P.K. "Composites Engineering Handbook». University of Michigan-Dearborn, 1997.

(17) Gay, D. «Matériaux composites». Éditions Hermes, 199.

(18) «Aerospace Structures». Edited by J. Loughlan. Elsevier Applied Science, 1990.

(19) Hull, D. «Materiales compuestos». Ed. Reverté, 1987.

(20) Mallick, P.K. «Fiber-Reinforced Composites». Marcel Dekker, Inc, 1993.

(21) Hollaway, L. «Polymer composites for civil and structural engineering». Blackie Academic \& Professional, 1993.

(22) Mallick, P.K. «Composite Materials Technology». New York: Oxford University Press, 1990.

(23) «Composite Materials in Aircraft Structures». Edited by D. H. Middleton. Longman, 1990.

(24) «Proceedings of ICCM9, Books I-VI». Edited by A. Miravete. Madrid, 1993.

(25) Clemente, R., Miravete, A., Larrodé, E., Castejón, L. «Polymer Composites and Polymeric Materiales», SAE publication SP-1351 pages 21-28, 1998 .

(26)Miravete, A., Castejón, L., Alba, J.J. «New Typologies of Fiberglass in the Transportation Secton», Materiales Compuestos 95, Asociación Española de Materiales Compuestos, pages 589-594, 1995. 